\title{
INOVASI PUSTAKAWAN MENGHADAPI PERUBAHAN DI MASA PANDEMI COVID-19
}

\author{
Arlan, S.I.Pust. \\ IAIN Bengkulu \\ e-mail: arlanfairuz@gmail.com
}

\begin{abstract}
Abstrak:
Tulisan ini mendeskripsikan tentang bagaimana pustakawan harus menyikapi perubahan akibat pandemi COVID-19 yang mengubah cara pandang tentang interaksi dengan pemustaka serta memaksa perpustakaan beradaptasi dan berinovasi menciptakan layanan dengan pendekatan berbeda. Inovasi hendaknya mempertimbangkan prinsip Five Laws of Library Science yang dikemukakan oleh Rangganathan (1931) dan dimodifikasi oleh Michael Gorman dalam New Five Laws of Library Science (1998). Pustakawan hendaknya meningkatkan kompetensi dan kualifikasinya untuk mendorong lahirnya inovasi. Nirliterasi pada generasi muda sebagai salah satu dampak pandemi covid-19 dapat menjadi celah inovasi pustakawan yang hendaknya dilakukan dengan semangat kolaboratif. Inovasi hendaknya didahului dengan pemetaan secara kongkrit mengenai permasalahan yang ada di sekitar sehingga hasil inovasi dapat diterapkan secara terstruktur, bertahap, dan terukur. Organisasi profesi pustakawan dapat mengambil peran lebih dalam berkontribusi memetakan masalah dan membuat rekomendasi strategi perbaikan literasi ke depan.
\end{abstract}

Kata kunci : COVID-19, perubahan, inovasi, kolaboratif, nirliterasi.

\begin{abstract}
:
This article illustrates how librarian should face the global change caused by pandemic COVID-19 that change the perspective of interaction with library user, and forced the library to be adaptive and innovative to build a library service in the new approach. Innovation shall be considere The FIVE LAW OF LIBRARY SCIENCE by Rangganathan (1931) and modified by Michael Gorman in NEW FIVE LAWS OF LIBRARY SCIENCE (1998). Librarian shall be enhanched their qualification and competency to create an innovation. Nirliterasi or unliterated in the young generation as one of the impact of pandemic covid-19 could be the chance for librarian innovation in the frame of collaborative spirit. Innovation shall be begin by congcret problems mapping for becoming implemented in structured, gradually, and measurably result Profession organization of librarian can be contributed more by mapping the problems arise and give recommendations for literacy strategy for the future.
\end{abstract}

Keywords : COVID-19, change, innovation, collaborative

\section{PENDAHULUAN}

Masyarakat di seluruh dunia saat ini sedang dalam kondisi darurat akibat menyebarnya virus SARS-CoV-2 yang menginfeksi manusia secara luas dan mengakibatkan korban kematian di seluruh dunia dalam jumlah yang cukup besar. Kondisi ini dikenal secara umum sebagai pandemi Covid-19. Virus ini merupakan virus jenis baru dan pertama kali tersebar di Kota Wuhan, China, dan hingga kini men- jangkiti hampir seluruh negara. Protokol kesehatan yang disosialisasikan WHO untuk mencegah dan mengurangi dampak penularan virus tersebut adalah melakukan jaga jarak (social distancing), rajin mencuci tangan, memakai masker, dan menghindari kerumunan orang, dan menyarankan agar lebih baik diam di rumah. Kegiatan masyarakat disarankan menggunakan fitur on line guna menghindarkan interaksi tatap muka, sehingga merebak dilakukannya bersekolah 
dari rumah (school from home) dan bekerja dari rumah (work from home). Bahkan lembaga internasional di bidang perpustakaan yaitu IFLA (International Federation of Library Associations) ikut memberikan panduan bagi perpustakaan dalam memberikan layanan selama masa pandemi berlangsung (IFLA, 2020). ${ }^{1}$

Perubahan besar besaran yang diakibatkan oleh pandemi covid-19 berdampak besar bagi siapapun, termasuk pustakawan. Hikmah yang bisa kita ambil dari peristiwa ini adalah bahwa perubahan akan selalu terjadi di dunia ini, dan pustakawan harus selalu mempersiapkan diri terhadap perubahanperubahan yang terjadi dan harus mampu bereaksi dan bertindak tepat agar tugas tugas kepustakawanan dapat tetap berjalan dalam keadaan apapun.

\section{TINJAUAN PUSTAKA}

\section{Pustakawan Dan Tujuan Perubahan}

Undang-undang Nomor 43 tahun 2007 tentang Perpustakaan mendefinisikan pustakawan sebagai seseorang yang memiliki kompetensi yang diperoleh melalui pendidikan dan atau pelatihan kepustakawanan serta mempunyai tugas dan tanggung jawab dalam pelayanan perpustakaan. Bagaimana tugas pokok pustakawan dijabarkan di dalam Permenpan Reformasi dan Birokrasi Nomor 9 tahun 2014 Pasal 4 dengan menyebutkan bahwa tugas pokok pustakawan

1 Suharso, Putut, etal. Layanan Perpustakaan Perguruan Tinggi dalam Menghadapi Pandemi Covid19. ANUVA Volume 4 (2) Semarang:Undip.2020: 272. yaitu melaksanakan kegiatan bidang kepustakawanan yang meliputi pengelolaan perpustakaan, pelayanan perpustakaan dan pengembangan sistem kepustakawanan. Sedangkan pada pasal 29 dinyatakan bahwa pustakawan dan tenaga teknis perpustakaan merupakan bagian dari Tenaga perpustakaan. Kewajiban tenaga perpustakaan dijelaskan pada pasal 32; (a) memberikan layanan prima terhadap pemustaka, (b) menciptakan suasana perpustakaan yang kondusif dan (c) memberikan keteladanan dan menjaga nama baik lembaga dan kedudukannya sesuai dengan tugas dan tanggung jawabnya.

Pustakawan, berdasarkan definisi tersebut, adalah seorang yang memiliki kualifikasi, kompetensi, tugas dan tanggung jawab dalam pelayanan perpustakaan. Peningkatan persyaratan dari aspek kualifikasi, kompetensi, tugas, dan tanggungjawabnya diarahkan untuk tujuan akhirnya yaitu peningkatan pelayanan perpustakaan yang lebih baik. Dengan demikian, tujuan pustakawan untuk berubah adalah untuk dapat memberikan pelayanan perpustakaan yang lebih baik sesuai dengan tuntutan zamannya.

\section{Perubahan dalam Dunia Perpustakaan}

Setidaknya terdapat 3 masa perubahan atau lebih tepatnya perkembangan yang dialami oleh dunia perpustakaan, yang dapat kita katakan sebagai era tradisional, era otomasi, dan era digital. Era tradisional ditandai dengan bahan pustaka berbasis kertas dengan sistem penelusuran koleksi 
menggunakan katalog kertas dan sistem manual. Berikutnya adalah era otomasi, dimana bahan pustaka kertas masih dominan digunakan tetapi aplikasi komputer membantu penelusuran koleksi yang tadinya manual menjadi online/terpasang yang dikenal dengan OPAC (Online Public Access Catalogue). Berikutnya adalah era digital, yang ditandai dengan pengalimediaan atau produksi file digital secara besar-besaran dan penelusurannya dapat melalui akses langsung menggunakan internet. Dilihat dari sisi layanan, perpustakaan tradisional dalam melayani pemustaka dilakukan secara manual demikian juga perpustakaan terotomasi juga masih manual dalam melayani pengguna. Berbeda dengan perpustakaan digital, segala bentuk layanan dapat dilakukan dengan bantuan komputer, bahkan peminjaman/ pengembalian koleksi dapat dilakukan secara mandiri oleh pemustaka.

Selain perkembangan, kita juga dapat menyaksikan pasang surut perpustakaan dalam sejarah. Pasang surut perubahan pada perpustakaan terjadi diantaranya diakibatkan oleh wabah, bencana alam maupun konflik, yang mengakibatkan perpustakaan rusak, bahkan musnah dan rata dengan tanah. Contohnya, perpustakaan-perpustakaan Islam yang mendunia pada masa silam hancur oleh invasi serangan tentara mongol. Di sisi lain, reruntuhan perpustakaan dapat kita temui sebagai peninggalan masa silam yang musnah akibat bencana alam seperti banjir, gempa bumi, letusan gunung berapi, dan lain sebagainya. Dan kini, kita menghadapi suatu wabah yang disebut sebagai pandemi covid-
19 yang memaksa kita untuk mengubah cara pandang tentang interaksi dengan pemustaka dan layanan perpustakaan.

Selain diakibatkan oleh lingkungan, perubahan juga dapat terjadi di dalam lingkungan internal perpustakaan. Hierarki struktur, manajemen, pola pekerjaan, visi dan misi, selalu mungkin untuk berubah. Perubahan-perubahan tersebut dapat berdampak kepada organisasi manajemen institusi perpustakaan, hubungan interaksi antara pemustaka dengan pengguna, dan perubahan tugas pokok dan fungsi perpustakaan yang menyesuaikan diri dengan dinamika dan perkembangan masyarakat dan kondisi lingkungan yang dihadapi.

\section{Kesiapan Pustakawan Menghadapi Pe- rubahan}

Mau tidak mau, siap tidak siap, pustakawan harus mau berubah. Berubah dalam arti meningkatkan diri agar mampu beradaptasi terhadap perkembangan keadaan dan kondisi internal dan eksternal perpustakaan. Bersiap dalam hal ini dimaknai sebagai memiliki sejumlah kompetensi yang memadai untuk dapat mengambil sikap dan keputusan yang tepat sebelum, pada saat, dan setelah perubahan terjadi.

Hal ini telah lama diwaspadai oleh Rangganathan, seorang pustakawan berkebangsaan India, yang pada tahun 1931 merumuskan lima hukum ilmu perpustakaan, yang dikenal dengan Five Law of Library Science. Kelima hukum ilmu perpustakaan tersebut adalah : 
1. book for use, buku untuk digunakan, bukan hanya untuk dikoleksi

2. every reader his or her book, setiap orang memiliki kebutuhan yang berbeda terhadap buku,

3. every book its reader, setiap buku pasti ada pembacanya, pasti ada manfaatnya,

4. save the time of reader, jangan membuang waktu pembaca, efektifkan layanan kepada pembaca,

5. library is a growing organization, perpustakaan adalah organisasi yang tumbuh dan berkembang.

Kelima hukum ini kemudian diadaptasi dan dikembangkan oleh Michael Gorman, seorang pustakawan di Perpustakaan Nasional Inggris, dan pada tahun 1998 Gorman menyatakan konsep New Five Law Of Library Science dengan memodifikasi prinsip sebelumnya menjadi;

1. Library serve humanity, perpustakaan melayani kemanusiaan tanpa membedakan suku, agama, ras,

2. Respect all form that which knowledge is communicated, menghargai seluruh bentuk dan media yang digunakan untuk mengkomunikasikan pengetahuan kepada masyarakat

3. Use technology to enhance service librarians, menggunakan teknologi untuk meningkatkan layanan perpustakaan

4. Protect free access to knowlege, melindungi kebebasan untuk mengakses pengetahuan

\section{Honor the past, create the future,} menghargai masa lalu, menciptakan masa depan. ${ }^{2}$

Rangganathan mengisyaratkan bahwa perubahan dalam organisasi perpustakaan adalah keniscayaan, sehingga pustakawan mau tidak mau harus selalu bertumbuh, berkembang, berubah, beradaptasi, mengikuti perubahan organisasi perpustakaan itu sendiri maupun tuntutan lingkungan masyarakat sesuai zamannya. Dalam menghadapi perubahan, Michael Gorman mendorong perpustakaan menciptakan pembaharuan tanpa meninggalkan masa lalu. ${ }^{3}$

\section{Daya Adaptasi, Kreatifitas, dan Inovasi Pustakawan}

Perubahan selalu dibarengi dengan proses penyesuaian atau adaptasi. Adaptasi adalah bentuk penyesuaian diri terhadap lingkungan, pekerjaan dan pelajaran (Suharso, 2009) ${ }^{4}$. Adaptasi juga dimaknai sebagai tindakan yang dilakukan seseorang untuk menjaga eksistensinya terhadap perubahan yang terjadi. Demikian pula dengan pustakawan, harus beradaptasi terhadap perubahan, dengan tujuan agar sesuai dengan tuntutan lingkungan, pekerjaan, dan pelajaran/ ilmu pengetahuan dan eksistensinya tetap terjaga di tengah gelombang peru-

2 Mafar,Fiqru.Rangganathan versus Gorman: Tinjauan atas Five Laws of Library Science. Jurnal Ilmu Budaya Vol.7 No. 2 tahun, 2011:60-64

3Ibid. Hal.65

4 Suharso dan Retnoningsih, Ana.Kamus Besar Bahasa Indonesia Edisi Lux. Semarang,Penerbit CV Widya Karya,2009 
bahan dan tidak tenggelam hingga mengalami kepunahan.

Bagaimana pustakawan beradaptasi terhadap perubahan? Terdapat ada 5 cara beradaptasi terhadap perubahan, yakni dengan cara konformitas, inovasi, ritualisme, retreatisme, dan rebellion. ${ }^{5}$ Berikut adalah penjelasannya:

1. Konformitas, adalah pilihan tindakan mencapai tujuannya dengan cara yang diterima oleh norma yang berlaku. Contohnya, jika ingin mudah diterima bekerja maka harus memiliki ijazah S1.

2. Inovasi, tindakan yang memiliki tujuan tetapi dengan cara yang mengabaikan norma yang berlaku di masyarakat. Misalnya, meningkatkan pendapatan dengan jalan korupsi, meraih nilai tinggi dengan cara mencontek/ plagiasi. Dalam pandangan Morton, inovasi dipandang tidak dinilai positif.

3. Ritualisme, tindakan tanpa tujuan, hanya menyesuaikan dengan norma yang berlaku. Seperti halnya pustakawan yang hanya sekedar bekerja dalam rutinitas, sesuai jam kerja, asal mendapat gaji.

4. Retreatisme, tindakan menarik diri dari sistem yang ada. Hidup tanpa memiliki tujuan, atau memiliki tujuan yang salah dan tidak sesuai norma yang berlaku. Pola adaptasi ini dapat dilihat pada orang yang mengalami gangguan jiwa, gelandangan, pemabuk dan para pecandu narkoba.

5 Mulyadi, etal. Adaptasi Pustakawan dalam Menghadapi Kemajuan Teknologi.Berkala Ilmu Perpustakaan dan Informasi Vol. 15 No.2 Desember 2019:166-167.
5. Pemberontakan, kebalikan dari retreatisme, adalah tindakan ingin mencapai tujuan dengan tidak mengakui sistem sebelumnya. Tidak lagi mengakui struktur sosial yang ada dan berupaya menciptakan struktur sosial yang baru. Tujuan yang ada dianggap sebagai penghalang bagi tujuan yang diharapkan. Tujuan dan caranya tidak sesuai dengan norma yang berlaku di masyarakat.

Konformitas sebagai cara adaptasi yang menyesuaikan tujuan diri dan organisasi dengan tujuan yang diterima masyarakat dengan memperhatikan norma yang berlaku hendaknya menjadi pilihan cara adaptasi pustakawan. Dengan konformitas, perubahan disikapi dengan positif dan mendukung nilai yang dianut masyarakat. Dikaitkan dengan upaya pustakawan menghadapi perubahan, maka adaptasi dengan cara konformitas yang dilakukan oleh pustakawan adalah meningkatkan kualifikasi dan kompetensi pustakawan.

Berbeda dengan Merton, Everett $\mathrm{M}$ Rogers mendefinisikan inovasi sebagai ide, praktek atau objek dilandasi dan diterima sebagai suatu hal yang baru bagi seseorang atau unit adopsi lainnya (organisasi). Inovasi menyajikan suatu alternatif atau cara yang baru bagi individu atau organisasi untuk menyelesaikan masalah ${ }^{6}$. Pembaruan, dalam hal atau cara yang baru dan belum pernah ada dalam masyarakat sebelumnya seringkali menimbulkan pro dan kontra. Masyarakat bersikap kontra atau menolak inovasi

6 Rogers, Everett M.Diffusion of Innovation Fourth Edition. New York.The Free Press.1995:xvii 
sebagai suatu hal yang baru karena, sebagaimana dalam definisi Merton, inovasi dicapai dengan tujuan yang benar tetapi cara yang salah karena berbenturan dengan kebiasaan dan norma masyarakat dan nilai agama, budaya, dan hukum. Misalnya, penyedap rasa untuk membantu melezatkan masakan menimbulkan penolakan karena mengandung unsur babi. Karenanya inovasi, sebagaimana definisi Rogers, sedapat mungkin sebagai hal baru, cara baru, yang tidak biasa, mungkin mengejutkan, menimbulkan pro kontra, tetapi tetap dalam kerangka nilai agama, budaya, dan hukum.

Dengan demikian, inovasi pustakawan dapat disimpulkan sebagai cara pustakawan beradaptasi menghadapi perubahan, yakni dengan menawarkan unsur kebaruan yang selama ini tidak ada dalam kebiasaan dan norma yang berlaku, tanpa melanggar nilai agama, budaya, dan hukum yang ditujukan untuk meningkatkan pelayanan perpustakaan.

Berdasarkan uraian tersebut, berikut adalah kerangka hubungan antara konsep perubahan, adaptasi, inovasi, kompetensi, dan peningkatan layanan perpustakaan dalam rangka bagaimana pustakawan menghadapi perubahan.

Perubahan mengharuskan pustakawan beradaptasi, yakni dengan melakukan konformitas dan inovasi. Konformitas dilakukan dengan meningkatkan kualifikasi dan kompetensi pustakawan, sementara inovasi dilakukan dengan menciptakan hal atau sistem baru. Pustakawan yang memiliki kompetensi memadai dapat berproses menciptakan suatu inovasi, tetapi jika kualifikasi dan kompetensinya kurang memadai, maka pustakawan melakukan konformitas dengan cara meningkatkan kompetensi dan kualifikasinya. Keseluruhan proses berujung kepada tujuan meningkatkan layanan perpustakaan agar sesuai dengan tuntutan perubahan. Jika kembali terjadi perubahan, maka dilakukan adaptasi kembali hingga layanan perpustakaan sesuai dengan tuntutan perubahan, dan siklus ini akan terus berulang.

Dengan demikian, agar pustakawan mampu berinovasi, maka perlu dilakukan peningkatan kompetensi dan kualifikasi terus menerus, sebagaimana kerangka hubungan antara konsep perubahan, adaptasi, inovasi, kompetensi, dan peningkatan layanan perpustakaan dalam rangka bagaimana pustakawan menghadapi perubahan sebagaimana diilustrasikan alurnya dalam Gambar 1.

Hasil penelitian Roni Rhodin menunjukkan bahwa kompeten saja tidak cukup untuk dapat melahirkan inovasi, pustakawan juga harus didukung oleh:

1. passion artinya pustakawan harus berjiwa semangat dan tidak mudah menyerah dalam melaksanakan aktivitas sebagai pustakawan.

2. time management, artinya pustakawan harus bisa mengatur waktunya sehingga 


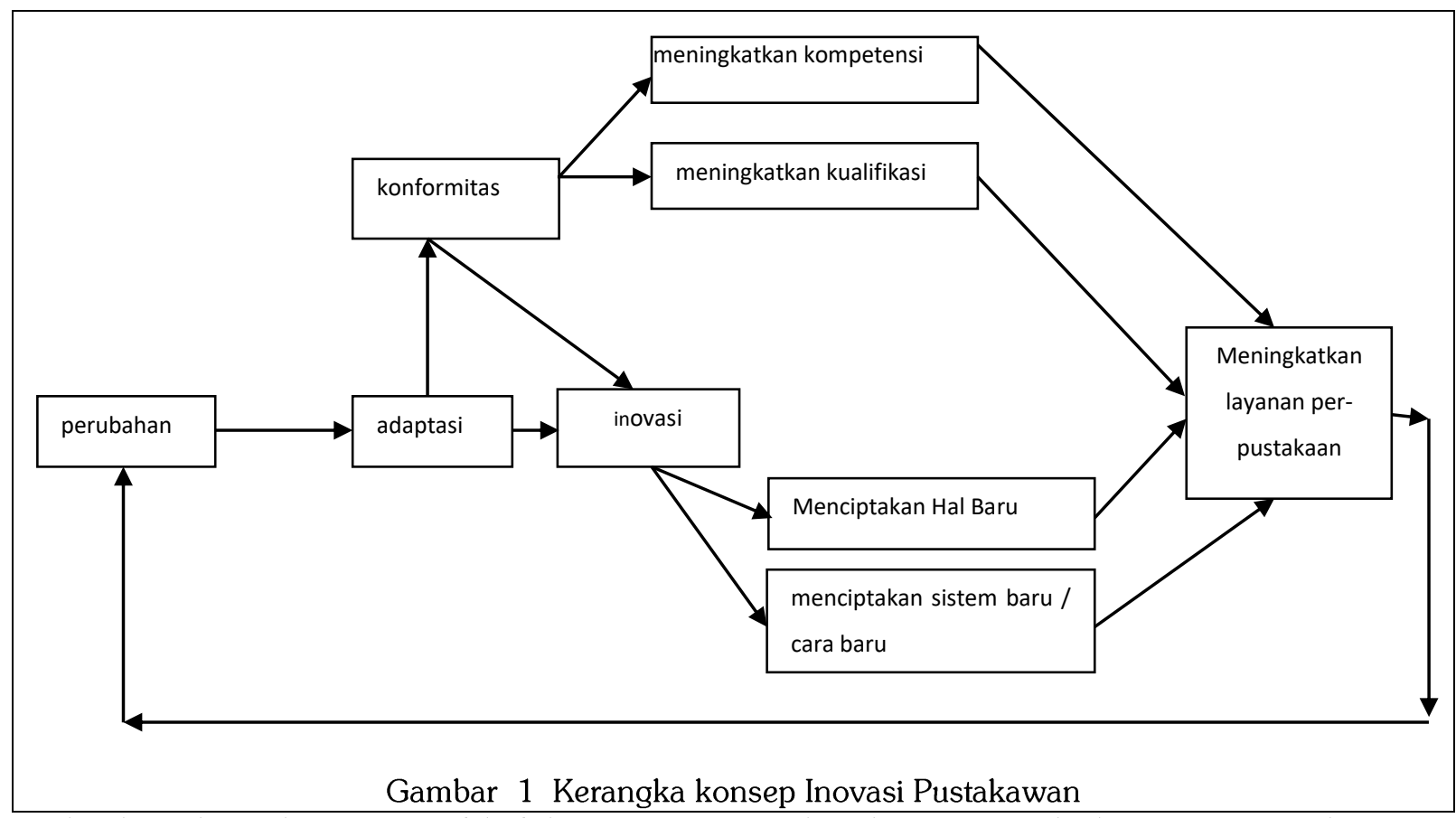

waktu bisa digunakan secara efektif dan bersikap arogan baik sesama pustakaefisien. wan maupun dengan pemustaka. ${ }^{7}$

3. networking artinya jaringan, pustakawan harus surrounding, artinya bisa menjalin komunikasi dan kerjasama baik sesama pustakawan maupun dengan profesi lainnya

dan staf lainnya dalam melakukan aktivitas profesinya.

4. Sense of competition artinya pustakawan harus punya semangat berkompetisi,

pustakawan harus terbiasa berada di tengah-tengah para pesaing sehingga pustakawan akan selalu siaga dan punya semangat untuk maju dalam hal karier dan profesionalitas.

5. humble artinya kerendahan hati, pustakawan tidak boleh berlaku dan

\section{Kompetensi Pustakawan}

Kompetensi dalam Kamus Bahasa Indonesia didefinisikan dengan pengetahuan, keterampilan, dan karakteristik pribadi yang sangat penting untuk mencapai keberhasilan pada suatu pekerjaan. Titik Kismiyati dalam paparannya mengenai Standar Kompetensi Perpustakaan menjelaskan "orang yang kompeten adalah orang yang menguasai pekerjaannya dan memiliki motivasi, keterampilan serta pengetahuan, dan secara konsisten menjalankan tanggung jawab tersebut. $^{8}$ Kompetensi dalam diri seseorang

7 Rhoni Rodin. Upaya Pustakawan Akademik Menumbuhkan Kreativitas dan Inovasi di Era Digital (Studi di Perpustakaan

Perguruan Tinggi Islam di Propinsi Bengkulu). Jurnal Al Maktabah,Vol.17, Desember 2018:8-10.

8 Hasbana, Amrullah. (2017). Standar Kompetensi Pustakawan sebagai Instrumen Asesmen Jabatan 
menurut Marshall, ditunjukkan dengan adanya:

1. Keterampilan, yaitu hal-hal yang orang bisa lakukan dengan baik

2. Pengetahuan, yaitu apa yang diketahui seseorang tentang suatu topik.

3. Peran sosial, yaitu citra yang ditunjukkan oleh seseorang di muka public

4. Citra diri, yaitu gambaran yang dimiliki seseorang mengenai diri sendiri

5. Watak, yaitu karakteristik yang mengakar pada diri sendiri

6. Motif, yaitu adalah pikiran-pikiran dan preferensi-preferensi tak sadar yang mendorong seseorang berperilaku. ${ }^{9}$

Pustakawan yang kompeten adalah sebagaiman yang dinyatakan dalam Peraturan Pemerintah Republik Indonesia Nomor 24 Tahun 2014 tentang Pelaksanaan Undangundang Nomor 43 tahun 2007 tentang Perpustakaan Pasal 32 ayat 3. Didalamnya disebutkan bahwa bahwa pustakawan, tenaga teknis perpustakaan, tenaga ahli dalam bidang perpustakaan, dan kepala perpustakaan memiliki tugas pokok, kualifikasi dan atau kompetensi. Pasal 34 merinci kompetensi yang dimaksud,yakni:

1. Pustakawan harus memiliki kompetensi profesional dan kompetensi personal,

2. Kompetensi profesional sebagaimana dimaksud di ayat (1) mencakup aspek pengetahuan, keahlian dan sikap kerja,
3. Kompetensi personal sebagaimana dimaksud pada ayat (1) mencakup aspek kepribadian dan interaksi sosial.

Dengan demikian, dapat dikatakan bahwa kompetensi profesional terkait dengan keterampilan, pengetahuan dan sikap terhadap pekerjaan dan peran sosialnya; kompetensi individu terkait dengan kepribadian dan interaksi sosial, yang mencakup pengembangan citra diri, watak, motif, serta komunikasi intra personal dan antar personal. Aspek-aspek tersebut dijabarkan lebih spesifik dalam deskripsi Canadian Association of Research Libraries tentang kompetensi pustakawan:

1. Foundational knowledge, mencakup pengetahuan tentang;

a. Sosial, budaya, ekonomi, politik dan informasi yang ada di lingkungan dimana pustakawan bekerja.

b. Perpustakaan dan praktik-praktik professional seperti etika, nilai-nilai dan prinsip dasar perpustakaan serta informasi profesi, peran perpustakaan dalam unit kerja serta sistem yang berjalan di dalam organisasi tempat perpustakaan berada (struktur, kebijakan, anggaran dan layanan).

c. Lingkungan ekstra institusional seperti daerah, provinsi, organisasi nasional dan internasional yang bisa mempengaruhi organisasi. 
d. Peraturan perundang-undangan yang berkaitan dengan perpustakaan dan pustakawan.

2. Interpersonal skills meliputi kemampuan beradaptasi, komunikasi dan advokasi efektif, negosiasi, manajemen perubahan, pengambilan keputusan, pemecahan masalah, inisiatif tinggi, mampu berinovasi dan berkolaborasi, promosi dan pemasaran, mentoring, keterampilan menulis serta mempresentasikan informasi-informasi mengenai perpustakaan.

3. Leadership and management adalah hal-hal yang berkaitan dengan bagaimana mempengaruhi dan memotivasi orang lain dalam membangun kerjasama dengan berbagai gaya, scenario dan organisasi belajar, memahami manajemen keuangan mulai dari prinsipprinsip perencanaan, penganggaran sampai pelaporan kegiatan, melakukan manajemen sumber daya manusia, serta mampu melakukan pengembangan terhadap layanan perpustakaan dengan menilai kebutuhan dan merencanakan serta melaksanakan layanan baru yang sesuai dengan kebutuhan pelanggan.

4. Collections development adalah kompetensi inti yang berkaitan dengan: siklus penerbitan ilmiah, pengembangan koleksi, digital curation, digital preservation, manajemen pelestarian koleksi, manajemen pelestarian koleksi dan manajemen rekaman mutu dan arsip data perpustakaan.
5. Information literacy adalah unsur penting yang harus dimiliki oleh pustakawan, dengan berkomitmen untuk mampu menginformasikan keaksaraan (sebagai bagian dari prinsip literasi informasi dalam lingkungan akademik, termasuk numeric dan keaksaraan data. Belajar dan mengajar untuk secara efektif berhubungan dengan pemangku kepentingan dan mengintegrasikan program literasi informasi yang sesuai, berpikir kritis dan belajar sepanjang hayat sebagai bagian dari upaya memahami konsep dan prinsip literasi informasi, sehingga pustakawan mampu memberikan pelayanan informasi dan memiliki pengetahuan tentang prinsip dan teknik untuk secara efektif berinteraksi dengan pengguna untuk menentukan kebutuhan informasi.

6. Research sebagai bagian dari kontribusi diri seorang pustakawan melalui penelitian atau publikasi, presentasi pada konferensi, pengajaran, manajemen kegiatan melalui kepanitiaan, terlibat dalam asosiasi profesional, pengabdian masyarakat serta mengembangkan teori atau projek baru.

7. Information technology skills sangat dibutuhkan oleh pustakawan meliputi pengetahuan tentang Integrated Library Systems (ILS), Web desain dan perkembangan sosial media, pengembangan sumber daya elektronik, sistem repositorydan sistem database. ${ }^{10}$ 
Definisi-definisi tentang kompetensi pustakawan pada akhirnya saling melengkapi sehingga menjadi arahan dan panduan bagi pustakawan dalam meningkatkan kompetensinya.

\section{Pendidikan dan Pelatihan Pustakawan}

Banyaknya kompetensi yang perlu dikuasai tentu membutuhkan banyak waktu dan kesempatan untuk dapat menguasainya, sementara pekerjaan rutin pustakawan saja terkadang menyita waktu. Menurut Amrullah Hasbana, pustakawan dapat menuangkan target kompetensi yang ingin ditingkatkan ke dalam uraian kerja yang menjadi tugas pustakawan sendiri. Berikan ruang ke dalam diri pustakawan sendiri untuk mengelaborasi, menginovasi dan mengkreatifikasi pekerjaannya sendiri. Kuncinya adalah pendidikan dan pelatihan pustakawan baik melalui jalur formal maupun non formal. Pendidikan dan pelatihan terhadap pustakawan diperlukan untuk memunculkan ide-ide baru yang kelak menjadi dasar bagi perkembangan dan perubahan pustakawan itu sendiri. ${ }^{11}$

Beragamnya jenis kompetensi yang diharapkan ada dalam diri pustakawan menunjukkan bahwa pustakawan seharusnya tidak membatasi dirinya dengan hanya mengikuti pendidikan dan pelatihan serta bentuk pendidikan lainnya (sosialisasi, workshop, seminar, dan sejenisnya) hanya

\footnotetext{
Diunduh dari https://www.carlabrc.ca/doc/core_comp_profile-e.pdf.

11 Hasbana, Amrullah. Standar Kompetensi Pustakawan sebagai Instrumen Asesmen Jabatan Fungsional Pustakawan. Op.cit. hal 71.
}

dalam bidang perpustakaan saja, karena persinggungan pustakawan dengan masyarakat penggunanya memiliki banyak segi dan bidang. Wawasan pustakawan terhadap bidang-bidang keilmuan lain pada saatnya akan bermanfaat dan menambah nilai hasil kreatifitas dan inovasi pustakawan. Sebagaimana yang dinyatakan oleh $\mathrm{Su}$ priyanto bahwa arah pengembangan pustakawan ditujukan agar mampu berperan serta melaksanakan dukungan secara rasional dan proporsional (kompeten) terhadap tugas pokok dan fungsinya sebagai wujud karakter pustakawan yang dikehendaki. Oleh karena itu diperlukan peningkatan profesionalisme dan membangun kreatifitas inovatif pustakawan. ${ }^{12}$

\section{MASA PANDEMI COVID-19 DAN INOVASI PUSTAKAWAN}

Di masa pandemi COVID-19 yang masih berlangsung hingga sekarang, sekolah, kampus, intansi pemerintah, dan masyarakat umum dikondisikan untuk belajar dan bekerja dari rumah dengan prinsip stay at home atau "tinggal di rumah saja" dengan protokol kesehatan ketat dengan tujuan untuk memutus rantai jaringan penyebaran virus. Karenanya kontak fisik antara pustakawan dengan pengguna selama beberapa waktu ditiadakan. Lalu bagaimana layanan perpustakaan kepada masyarakat? Akankah terhenti?

12 Supriyanto.Masa Depan Pustakawan di Era Digital, dalam Marsela. Jurnal Ikatan Pustakawan Indonesia Vol.4 .No. 1 dan 2 tahun 2012. Jakarta:Ikatan Pustakawan Indonesia.2012. 
Bagi pustakawan, terhentinya kontak fisik serta menurunnya frekuensi dan intensitas layanan terhadap pemustaka, di satu sisi merupakan kesempatan untuk melakukan introspeksi mengenai kapasitas, kapabilitas, dan kompetensinya sebagai pustakawan. Banyaknya kesempatan peningkatan kompetensi dengan munculnya berbagai tawaran seminar bahkan diklat melalui internet dapat dimanfaatkan sebaikbaiknya oleh pustakawan untuk mendukung tugas pokok dan fungsinya. Kompetensi yang hendaknya ditingkatkan tidak hanya meliputi kompetensi profesional tetapi juga kompetensi personal. Kedua jenis kompetensi ini membuat pustakawan tidak hanya harus memiliki kepedulian terhadap permasalahan di seputar tempat kerjanya tetapi juga permasalahan bangsa secara umum, terlebih pandemi COVID-19 telah semakin menjauhkan upaya upaya peningkatan literasi anak bangsa dari tujuannya. Terhentinya layanan perpustakaan umum, sekolahsekolah beserta perpustakaan sekolahnya membuat persoalah nirliterasi pada generasi muda semakin pelik solusinya.

\section{Dampak Pandemi terhadap Nirliterasi}

Layanan perpustakaan terpaksa harus berhenti karena situasi pandemi COVID-19. Amri Mahbub Alfathon, seorang Filolog di Perpustakaan Nasional RI, dalam tulisannya "Pustakawan dan Pandemi Literasi", menyatakan bahwa Indonesia tak hanya sedang menghadapi wabah COVID-19 yang sudah berjalan beberapa bulan ini, melainkan juga harus melawan "pandemi" lain yang telah lama terjadi dan belum berakhir hingga kini yakni "nirliterasi"."13

Lukman Solihin dkk. yang mengupas masalah nirliterasi ini dalam penelitiannya menengarai titik kritis nirliterasi terletak pada kurangnya literasi membaca di kelas awal. Menurutnya siswa yang tidak mampu membaca akan mengalami "efek Matthew" berupa menurunnya motivasi belajar, rendahnya kemampuan menangkap informasi, berpotensi mengulang kelas, bahkan tidak melanjutkan pendidikan/ drop out Hasil penelitiannya menunjukkan terdapat tiga persoalan utama terkait penyebab darurat literasi membaca di kelas awal, yaitu rendahnya kompetensi guru, kurikulum yang mengabaikan pelajaran membaca permulaan, dan minimnya sumber daya bacaan. ${ }^{14}$

Penelitian Solihin dkk. tentang adanya darurat literasi ini berawal dari data Hasil Early Grade Reading Assessment (EGRA) yang digunakan untuk mengukur kemampuan membaca siswa SD kelas awal yang dilakukan di 7 provinsi di Indonesia. Hasilnya diketahui bahwa siswa kelas 2 dan 3 umumnya dapat membaca kata dalam Bahasa Indonesia, namun tidak paham maknanya. Terkait tingkat pemahaman terhadap bacaan, hasil EGRA ini juga menunjukkan bahwa siswa di Jawa dan Bali dapat membaca dan memahami lebih baik dibandingkan siswa di daerah lain. Sementara siswa dari daerah

\footnotetext{
13 Alfathon, Amri Mahbub. Pustakawan dan Pandemi Nirliterasi, 2010.2 diunduh dari https://republika.co.id/berita/qd8u11385/ pustakawan-dan-pandemi-nirliterasi

14 Solihin, et.al. Darurat Literasi Membaca Di Kelas Awal: Tantangan Membangun SDM Berkualitas. Masyarakat Indonesia, Vol. 46 (1), JUNI 2020: 36
} 
timur Indonesia membaca dengan tingkat pemahaman paling rendah. Kondisi demografi pun turut mempengaruhi dengan ditemukannya kesenjangan antara siswa di daerah terpencil dengan mereka yang tinggal di daerah non-terpencil. Temuan serupa juga diperoleh dari hasil Asesmen Kompetensi Siswa Indonesia (AKSI) yang mengukur kemampuan membaca, matematika, dan sains bagi siswa kelas 4 SD. Hasil Aksi secara nasional menunjukkan, untuk kategori kurang dalam kemampuan matematika sebanyak $77,13 \%$, kurang dalam membaca $46,83 \%$, dan kurang dalam sains $73,61 \%$. Dengan demikian, hampir setengah dari siswa kelas 4 SD memiliki kemampuan di bawah rata-rata dalam membaca. Kondisi lemahnya kemampuan membaca itu terus terjadi, sehingga ketika PISA melakukan penelitian diperoleh data lebih dari 55\% anak usia 15 tahun buta huruf secara fungsional, artinya dapat membaca teks namun tidak mampu menjawab pertanyaan yang berkaitan dengan teks tersebut. Kondisi rendahnya kecakapan membaca di kelas awal ibarat kondisi tengkes (stunting) dalam dunia kesehatan. Pada anak dengan kondisi tengkes, periode emas perkembangan otaknya terhambat karena kurangnya asupan nutrisi. Akibatnya, kapasitas intelektual anak tidak berkembang optimal. Begitu pula dengan lemahnya literasi membaca dapat mempengaruhi terhadap keberhasilan anak dalam mengarungi dunia pendidikan. Siswa yang tidak mampu membaca dengan baik akan mengalami banyak hambatan dalam belajar. Stanovich menyebutnya sebagai "efek Matthew", yaitu dampak bagi siswa yang tidak bisa membaca dengan baik di kelas awal akan kehilangan motivasi, hanya mampu menyerap sedikit informasi, serta tidak mampu memahami informasi yang kompleks. Akibatnya, siswa bukan hanya gagal belajar, melainkan berpotensi besar mengulang kelas bahkan tidak melanjutkan pendidikan. Sebuah penelitian terhadap pelajar di Amerika Serikat mengungkapkan, para pelajar yang tidak dapat membaca lancar di akhir kelas 3 sekolah dasar memiliki risiko empat kali lebih besar meninggalkan bangku sekolah (drop out) tanpa mendapat ijazah dibandingkan mereka yang lancar membaca. $^{15}$

Dengan adanya pandemi COVID-19, kondisi nirliterasi atau darurat literasi meluas, tidak hanya terjadi di kelas awal (kelas 1-3 $\mathrm{SD)}$ tetapi juga merambat ke kelas lanjutan meski telah berusaha diatasi dengan modelmodel pembelajaran jarak jauh atau melalui perangkat teknologi komunikasi, karena sangat jelas, selain pelajaran membaca permulaan bagi kelas awal terabaikan karena minim kontak fisik antara guru dan murid, sumber daya bacaan juga tidak sampai ke tangan generasi muda bangsa ini dengan ditutupnya layanan perpustakaan sekolah, bahkan perpustakaan umum.

Kondisi ini diperberat dengan lambatnya roda pergerakan ekonomi akibat 
pandemi COVID-19. Banyaknya PHK, perusahaan gulung tikar, pendapatan menurun, dan melonjaknya prosentase masyarakat kurang sejahtera/prasejahtera/miskin. Karenanya nirliterasi tidak hanya menimpa generasi muda tetapi juga masyarakat secara umum.

\section{Nirliterasi dan Inovasi Pustakawan di Masa Pandemi COVID-19}

Inovasi pustakawan di masa pandemi COVID-19 secara umum adalah memfasilitasi pemustaka dengan layanan dalam jaringan/ online melalui penggunaan teknologi komunikasi, jaringan internet, dan media digital. Perguruan tinggi adalah institusi yang cenderung lebih siap menggunakan inovasi ini karena secara umum perpustakaannya memiliki kesiapan infrastruktur dan sumber daya manusia yang memadai dan pemustakanya memiliki kewaspadaan/ awareness yang cukup tinggi dalam menggunakan infrastruktur layanan online. Inovasi jenis ini meski sesuai dengan tuntutan protokol kesehatan di masa pandemi COVID-19 hanya bisa diterapkan secara terbatas dan tidak bisa diterapkan secara luas bagi pemustaka dari kalangan pelajar dan masyarakat umum akibat ketidaksiapan infrastruktur dan SDM di satu sisi dan kondisi pemustaka di sisi lain.

Terkait nirliterasi, hasil penelitiannya Solihin dkk. dapat menjadi fokus masalah yang bisa diangkat oleh pustakawan untuk mencari model inovasi yang sesuai, yakni adanya darurat literasi membaca di kelas awal akibat rendahnya kompetensi guru, kurikulum yang mengabaikan pelajaran membaca permulaan, dan minimnya sumber daya bacaan (Solihin dkk., 2020) ${ }^{16}$. Pustakawan bisa fokus kepada penyebab ketiga, yakni minimnya sumber daya bacaan, yang dalam perspektif kepustakawanan adalah meningkatkan aksesibilitas pemustaka kepada sumber daya koleksi.

Menurut Dr. Anindito Aditomo (2015), terdapat lingkaran kebaikan literasi dan lingkaran setan nirliterasi. Pada lingkaran kebaikan literasi melalui aktifitas membaca akan memperkaya kosakata melalui kegiatan menyimpulkan arti kata yang diperoleh dari konteks cerita. Kosakata yang semakin kaya memudahkan membaca teksteks baru, yang kemudian semakin memperkaya lagi perbendaharaan kata, juga memperkaya pengetahuan tentang topik, struktur teks dan seterusnya. Semakin sering membaca, seseorang akan semakin merasa sebagai "seorang pembaca" dan juga merasa "bisa membaca". Dengan kata lain, membaca membentuk konsep diri sekaligus efikasi diri. Keduanya sangat penting terutama ketika seseorang menghadapi bacaan yang terasa sulit. Seseorang yang memiliki identitas sebagai "seorang pembaca" akan lebih mau bertahan dan meneruskan bacaan yang sulit. Sementara kebalikannya, lingkaran setan nir-literasi terjadi pada orang yang jarang membaca juga jarang berkesempatan menambah kosakata dan pengetahuan tentang struktur teks. Strategi membaca juga tidak berkembang, pun demikian dengan identitas dan efikasi dirinya sebagai pembaca. Semakin stagnan kosakata, penge-

16 Ibid, hal. 37 
tahuan, identitas, dan efikasi diri, semakin enggan ia membaca, dan seterusnya ${ }^{17}$. Dengan demikian, untuk membentuk lingkaran kebaikan literasi, masyarakat harus didekatkan kepada sumber daya bacaan dan menjaga agar akses kepada sumber daya bacaan bisa berlangsung secara terus menerus.

Dengan kata kunci inovasi untuk mempertinggi aksesibilitas pemustaka kepada sumber daya bacaan secara terus menerus dan berkesinambungan, pustakawan dapat bercermin dari inovasi serupa yang telah dilakukan. Berikut adalah beberapa inovasi tersebut:

\section{a. BULIR/ BUKU BERGULIR}

Buku Bergulir (Bulir) adalah paket buku yang digulirkan kepada keluarga,setiap keluarga memperoleh pinjaman buku sesuai dengan kebutuhan dan minat keluarga penerima program buku bergulir, ada buku untuk ayah, ibu dan anak. Hal ini membantu masyarakat untuk bisa mengakses buku bacaan sesuai kebutuhan tanpa harus mengeluarkan biaya. Bulir merupakan program kerjasama antara Pemerintah Kota Solok melalui Dinas Perpustakaan dan Kearsipan Kota Solok bekerjasama dengan Yayasan Gemar Membaca Indonesia (Yagemi). Berdasarkan evaluasi pelaksanaan program Buku

\footnotetext{
17 Aditomo, Anindito.(2015.) Memutus Lingkaran Setan Nir-literasi. Diunduh dari http://www.ninoaditomo.com/2015/08/memutuslingkaran-setan-nir-literasi.html
}

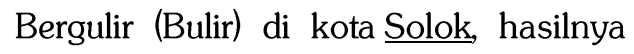
rata rata warga Kota Solok membaca 24 judul buku dalam setahun. Program Bulir kemudian dikoordinasikan oleh aparatur pemerintahan tingkat kelurahan di setiap wilayah Kota Solok dan didistribusikan ke masing-masing rumah penerima. ${ }^{18}$

b. HALO PEMUSTAKA

Program HALO PEMUSTAKA merupakan program layanan antar jemput peminjaman buku gratis selama wabah covid-19 bagi siswa sekolah dasar dan TK/PAUD sederajat yang diselenggarakan oleh Dinas Perpustakaan dan Kearsipan Kabupaten Pamekasan. Peminjaman Buku-buku PAUD dan TK gratis diantar dan dijemput radius $10 \mathrm{Km}$ dari Kantor Perpustakaan Setiap harinya 50 buku disiapkan untuk diantarkan dengan 2 armada. Asesmen kebutuhan buku dilakukan dengan menyediakan katalog melalui aplikasi komunikasi Whatsapp. ${ }^{19}$

c. Pustaka Bergilir Buku Masuk Rumah (PB-BMR)

Pustaka Bergilir Buku Masuk Rumah (PB-BMR) adalah sistem penyediaan

18 Khadijah.Program Bulir Warga Kota Solok Baca 24-Buku Setahun. Klikpositif.com:27 September 2019. Diunduh dari https://webtorial.m.klikpositif.com/baca/58033/progra m-bulir-warga-kota-solok-baca-24-buku-setahun.

19 Kabarmadura.id.DPK Pamekasan Promosikan Paket Inovasi Halo Pemustaka. 21 Juli 2020. diunduh dari: https://kabarmadura.id/dpk-pamekasanpromosikan-paket-inovasi-halo-pemustaka/ 
dan pengantaran buku bacaan ke rumah-rumah yang sesuai untuk keluarga Indonesia. Buku diantarkan secara bergilir ke rumah-rumah setiap 15 hari oleh petugas. Program ini relevan dengan kondisi terbatasnya bacaan masyarakat. Apa lagi di saat larangan berkumpul, maka perpustakaan di daerah tidak dapat dikunjungi, sekolahpun harus di rumah. Setiap orang dalam keluarga dapat membaca 24 judul buku dalam setahun. Program ini ditujukan untuk mempercepat program penguatan kemampuan literasi masyarakat desa sebagaimana yang diprogramkan pemerintah. Program ini merupakan strategi jangka panjang agar kehidupan masyarakat Indonesia menjadi lebih baik. Sebelumnya, program ini telah mengalami serangkaian proses dari pengembangan dan uji coba langsung melalui program Gerakan Nagari Membaca di Nagari Paninjauan, Kabupaten Solok, Sumatera Barat tahun 2014-2015 dan percontohan di Nagari Saoklaweh tahun 2016-2018 dengan jumlah rumah 950 rumah, 4.233 jiwa dengan 4.750 buah buku. Desa percontohan ini meraih juara 1 tingkat nasional pada Lomba Perpustakaan Umum Terbaik (Desa/Kelurahan) tahun 2018. Sistem ini juga sudah tercatat sebagai Hak Cipta PB-BMR, yang ditetapkan melalui Surat Hak Cipta dari Kementerian Hukum dan Hak Asasi Manusia.
Berdasarkan uji coba tersebut, keunggulan sitem ini antara lain adalah setiap orang dalam rumah (bapak, ibu, dan tiga orang anak) dapat membaca paling sedikit 24 judul buku bacaan. Hal ini menguatkan pondasi literasi sejak dini dalam keluarga. Karena ini bersifat masal, maka harga buku menjadi murah sehingga meringankan beban belanja negara, dan dapat menjangkau semua lapisan masyarakat. Diharapkan, melalui program ini, logika dan nalar masyarakat tertata dengan baik sehingga akan lebih mudah bertahan dan mampu berpikir mencari jalan keluar mengatasi masalah kehidupan yang sulit. Program ini dilakukan dengan terencana, terstruktur, dan terukur. ${ }^{20}$

\section{KESIMPULAN}

Ketiga contoh di atas menunjukkan bahwa inovasi untuk mengatasi nirliterasi di masa pandemi covid-19 dilakukan melalui peningkatan aksesibilitas masyarakat terhadap bahan bacaan secara fisik. Pola inovasinya adalah metode antar jemput koleksi yakni langsung mengantarkan sumber daya bahan bacaan dari rumah ke rumah dan menjemputnya kembali pada waktu yang ditentukan. Polanya dapat digambarkan sebagai berikut;

\section{i. Program Bulir}

\footnotetext{
20 Kelana, Irwan.Yagemi Siapkan Program Buku Masuk Rumah.2020. diunduh dari https://republika.co.id/berita/q8lcqz374/yagemisiapkan-

program-buku-masuk-rumah
} 
ii. Pemerintah daeah $\rightarrow$ Perpustakaan umum/DPK + Organisasi Sosial $\rightarrow$ aparat kelurahan $\rightarrow$ rumah/ keluarga.

iii. Program HALO PEMUSTAKA

iv. Perpustakaan umum/DPK $\rightarrow$ pustakawan/ petugas perpustakaan $\rightarrow$ rumah/anak

Program Pustaka Bergilir Buku Masuk Rumah (PB-BMR)

Organisasi Sosial $\rightarrow$ relawan $\rightarrow$ rumah/ keluarga

Inovasi yang dilakukan oleh instansi perpustakaan umum, organisasi sosial masyarakat, dan organisasi profesi pustakawan ini menjadi cermin bahwa dalam mengembangkan inovasi pustakawan dapat bergabung bersama-sama dengan lembaga perpustakaan, organisasi sosial masyarakat, atau organisasi profesi pustakawan untuk menuangkan pikiran dan ide-idenya untuk membuat inovasi gerakan yang lebih besar. Pustakawan yang berada dalam organisasi profesi dapat digerakkan sebagai relawan mediator antara lembaga penyedia bahan bacaan/ perpustakaan atau komunitas/ organisasi sosial masyarakat dengan masyarakat. Melalui kompetensinya, pustakawan dapat dikoordinasikan untuk membuat assessment kebutuhan, perencanaan serta pelaksanaan hingga pelaporan dan evaluasi yang terstruktur, bertahap, dan terukur, sehingga kondisi literasi masyarakat dapat terpantau. Jika dilakukan secara massif, hal ini dapat menjadi bahan kajian bagi pendataan literasi wilayah di satu sisi dan peluang emas untuk melakukan penelitian dan kajian bagi peningkatan profesionalitas dan menambah angka kredit pustakawan di sisi lain. Organisasi profesi pustakawan seperti IPI dapat mengambil peran lebih dalam berkontribusi memetakan masalah dan membuat rekomendasi strategi perbaikan literasi ke depan. Hasil akhir dari semua itu adalah terprogramnya kegiatan literasi secara nasional sehingga pada akhirnya dapat mengatasi darurat literasi di titik yang paling kritis untuk membantu meletakkan dasar kemampuan literasi anak bangsa untuk masa depan yang lebih baik.

\section{Daftar Pustaka}

Aditomo, Anindito. 2015. Memutus Lingkaran Setan Nir-literasi. Diunduh dari : http://www.ninoaditomo.com/2015 /08/memutus-lingkaran-setan-nirliterasi.html

Alfathon, Amri Mahbub 2010 Pustakawan dan Pandemi Nirliterasi, diunduh dari https://republika.co.id/berita/qd8u1 1385/ pustakawan-dan-pandeminirliterasi

Amrullah Hasbana 2017 Standar Kompe tensi Pustakawan sebagai Instrumen Asesmen Jabatan Fungsional Pustakawan. Al-Maktabah Vol. 16, Desember 2017,68-79.

carl-abrc.ca. 2010. Core Competencies for 21st Century Carl Librarians, Cana dian Association of Research Librar ies.

Kelana, Irwan. 2020. Yagemi Siapkan Program Buku Masuk Rumah. Diunduh dari :https://republika.co.id/berita/q8lcq 
z374/yagemi-siapkan-programbuku-masuk-rumah

Kementerian Pendayagunaan Aparatur Negara. (2002). Peraturan Menteri Pendayagunaan Aparatur Negara Nomor: 132/KEP/M.PAN/12/2002

Kementerian Pendayagunaan Aparatur Negara dan Reformasi Birokrasi Republik Indonesia. 2014. Peraturan Menteri Pendayagunaan Aparatur Negara dan Reformasi Birokrasi Republik IndonesiaNomor 9 tahun 2014.

Khadijah. Program Bulir Warga Kota Solok Baca 24 Buku Setahun. Diunduh dari:

https://webtorial.m.klikpositif.com/b aca/58033/program-bulir-wargakota-solok-baca-24-buku-setahun.

Lukman Solihin, Indah Pratiwi, Genardi Atmadiredja , \& Bakti Utama . Darurat Literasi Membaca Di Kelas Awal: Tantangan Membangun SDM Berkualitas. Masyarakat Indonesia, Vol. 46 (1), JUNI 2020 diunduh dari http://jmi.ipsk.lipi.go.id/index.php/j miipsk/article/viewFile/914/566

Mafar, Fiqru. 2011. Rangganathan versus Gorman: Tinjauan atas Five Laws of Library Science. Jurnal Ilmu Budaya Vol.7 No. 2 tahun 2011: 57-117. diunduh dari : https://media.neliti.com/media/publ ications/100140-ID-none.pdf

Mulyadi\& Iskandar Zulkarnain\& Nurdin Laugu.(2019). Adaptasi pustakawan dalam menghadapi kemajuan teknologi . Berkala Ilmu Perpustakaan dan Informasi, Vol. 15 No. 2, Desember 2019, hal. 163$174 . \quad$ Diunduh dari :https://www.researchgate.net/publi cati-

on/337225588_Adaptasi_pustaka wan_dalam_menghadapi_kemajuan teknologi/link/5dcc4234a6fdcc7e 137e2c93/download

Perpustakaan Nasional Republik Indonesia.(2014).Peraturan Bersama Kepala Perpustakaan Nasional Republik Indonesia dan Kepala Badan Kepegawaian Negara Republik Indonesia Nomor 8 Tahun 2014 dan Nomor 32 Tahun 2014.
Perpustakaan Nasional Republik Indonesia.(2015).Peraturan Kepala Perpustakaan Nasional Republik Indonesia Nomor 11 Tahun 2015 tentang Petunjuk Teknis Jabatan Fungsional Pustakwan dan Angka Kreditnya.

Rhoni Rodin 2018. Upaya Pustakawan Akademik Menumbuhkan Kreativitas dan Inovasi di Era Digital (Studi di Perpustakaan Perguruan Tinggi Islam di Propinsi Bengkulu). Jurnal Al Maktabah,Vol.17, Desember 2018.

Rogers, Everett M. 1995. Diffusion of Innovation Fourth Edition. New York:The Free Press.

Solihin,et.al. (2020).Darurat Literasi Membaca Di Kelas Awal: Tantangan Membangun SDM Berkualitas. Masyarakat Indonesia, Vol. 46 (1), Juni 2020.

Supriyanto, (2012).Masa Depan Pustakawan di Era Digital, dalam Marsela. Jurnal Ikatan Pustakawan Indonesia Vol.4 no. 1 dan 2 tahun 2012. Jakarta. Ikatan Pustakawan Indonesia.

Undang-undang Nomor 43 tahun 2007 tentang Perpustakaan

Undang-undang ASN (Aparatur Sipil Negara) nomor 5 tahun 2014

Suharso, Putut, et.al.(2020). Layanan Perpustakaan Perguruan Tinggi dalam Menghadapi Pandemi Covid-19. ANUVA Volume 4 (2): 271-286, 2020. Diunduh dari: https://ejournal2.undip.ac.id/index.p $\mathrm{hp} / \mathrm{anuva} /$ article/view/8185

https://kabarmadura.id/dpk-pamekasanpromosikan-paket-inovasi-halopemustaka/ 